\title{
Developing Playing Activity Models in Physical Education towards Improving Multilateral Abilities among Elementary School Students
}

\author{
Ilham Eryk Pratitis Robinson \\ Master Program in Sport Sciences \\ Universitas Negeri Yogyakarta \\ Yogyakarta, Indonesia \\ robin.280592@gmail.com
}

\author{
Sri Winarni \\ Faculty of Sport Sciences \\ Universitas Negeri Yogyakarta \\ Yogyakarta, Indonesia \\ sri_winarni@uny.ac.id
}

\begin{abstract}
- the purpose of this study is to develop a model of playing activity in Physical Education learning that can be used to improve multilateral abilities in elementary schools' students. This model of playing activity can be used as a teaching guide while learning and teaching sports in elementary schools. And the product developed is in the form of books equipped with instructions so that the teachers can easily understand and implemented them. It is a Research and Development (R\&D) study consisting of several steps of development which include: the preliminary phase consisting of the collection of data through field surveys and data analysis, planning stage, development stage (gathering theories related to the product), expert validation, revision phase 1 , small-scale trial, revision phase 2, large-scale trial, final product and product diffusion. The sample of this study was an elementary school under the Yogyakarta Region Coordinator in the South Area of Yogyakarta City Education Office. And purposive sampling technique was used in selecting the subjects which include: a small trial group from a class of 30 students aged 6-9 years, a Physical Education teacher, an expert in multilateral coaching, and an expert in motoric education.. Also, a large trial group from two classes with 60 students from ages 6-10 years, two Physical Education teachers, an expert in multilateral coaching, and an expert in motoric education. The result of this research are in form of a playing activity models that consisting of 25 different types of playing activities which are packaged in the form of a book guide. And in overall, the implementation of the models are feasible
\end{abstract}

\section{Keywords—playing, model, physical education, multilateral}

\section{INTRODUCTION}

Sport is a modern cultural entity that is accepted worldwide.. Its power is spreading and its attraction is traceable to the ontological roots of its emergence expressed in the nature of play.. Johan Huizinga, in his thesis titled Homo Ludens, has it that sport is the result of progression from the form of play which is believed to be one of human nature. For this reason, it is hard to separate sport from human life.

In Indonesia, the government is actually giving the required attention to its developmental activities which is seen in the establishment of a body managing sport activities in the country, the Ministry of Youth and Sports. Also, government efforts in developing sports are evidence in the ratification of Law No. 3 of 2005 which has deals with: (1) sports achievement, (2) educational sports, and (3) recreational sports. And in trying to discuss the efforts geared towards developing sports from its lowest point on the Indonesian pyramid of education, what is done in the classroom comes to mind. School activities in classrooms through Physical Education, aim at developing aspects of health, physical fitness, critical thinking skills, emotional stability, social skills, reasoning and moral actions. This is in accordance with the findings of Baley and Field in Freeman that, "Physical education is a process through which favorable adaptations through organic learning, neuromuscular, intellectual, social, cultural, emotional developments are achieved through the selected fairly vigorous physical activities" [1]. From the explanation above, it is obvious that the substance of physical education is basically a teaching experience consisting of human movements packaged in an essential, factual, and actual experience content. Therefore, the aim of this material is to provide students with natural growth and development in the three domains of learning: psychomotor, cognitive, and affective domains. Also, it should be noted that the purpose of physical education is not only for physical development, but also spiritual, as the physical is just a means of learning so as to achieve both goals [1]. And same physical education can be used to improve motor skills, fitness, knowledge, social, and beauty level of an individual. [2]. More so, physical education could help in self discovery, forming an ideal body, maintaining one's fitness and health, just to mention few. [3]. Thus, the basic goal of physical education is to develop various movement skills, attitudes, and the foundation of students' personalities achieved through physical activities.

Right from school, children start to acquire knowledge on how to properly exercise their bodies which is done under the guidance of a sports teacher. By doing this, it is expected that these children can develop their potential. But in reality, the existence of schools is always ignored in the discourse of achievements as well as analysis of sport developments. This should not be, because in the real sense, the achievements experienced in the sports won't be possible without the foundational knowledge in the classrooms. Therefore, 
physical education is one of the most appropriate tools needed to develop children's potential based on educational activities wrapped in it. And talking about the development of Physical Education in the present context, it is not a simple matter. Some of the challenges witnessed are in the areas of facilities made available in schools. Most of these schools use the lack of the needed infrastructure as an excuse for not running some of these beneficial activities. Also looking at the current conditions of schools, especially in urban areas, it is clear that most of them have no land left dedicated for their students physical activities. But some of them improvised by getting open spaces that might involve their students walking a distance of $1 \mathrm{~km}$ or more for any physical activity thereby limiting what these students can do on their own. And for those that have spaces, they are more concerned with the expansion of their schools in the area of building more classes or laboratories so as to accommodate more students and placing little importance on their students' physical education. . The direct consequence of this is that many of these children's potentials in the area of sports would not be developed.

Another profound problem in developing sports is the availability of competent teachers. Physical Education will not have the expected impact on the students if the teachers taking them the subject lack the needed skills.. The role of teachers is very important and strategic in the efforts put in place to improve the quality of education. Many studies carried out concluded that qualified teachers have a big influence on the effectiveness of learning and affect student achievement [4]. According to Rink and Siedentop, one important indicator of teacher's quality is the extent to which he is able to effectively carry out the learning process [5]. And this effectiveness is basically a reflection of how the teacher is able to manage processes involved in the learning activities. Meanwhile, managing these activities is not done by one person, it is basically a process of pedagogical interaction between the teacher, the students, learning materials, and the environment where that learning is taking place and the most important act is done by the teacher. But when the teacher is not carrying out his duty as ought to, it negatively impacts the students motivation thereby making it impossible for them to achieve the primary goal of the whole process.

Apart from the knowledge impacted by teacher, he has the responsibility of paying attention to the interests of each student based on their differing abilities. This is one of the most important principles in Physical Education, which is the principle of overall and equitable participation of students. For example, he should know how to handle those having some disabilities or those with abnormal development. The key here is the ability to balance things among his students as he is not only to focus on training students to be outstanding, but also to have fun, maintain some level of fitness and develop other personal values through those physical activities.

In trying to stimulate a child's growth and development, in sporting activities and both intellectually and emotionally, a child need to be exposed and involved to the required activities at an early stage. This has proven to be very effective in terms of results. Some of these activities in sports are important ingredients they need to face some future challenges and for this reason, they should be designed in accordance to the growth and developmental needs of each child. They can introduced to things about objects and people around them through sports activities. And knowing the various patterns, attitudes, behaviors, habits and properties of these objects and people around them help them to have a better understanding of the psychological aspects of their social environment. Ages 6-8 years are the gold age to initiate the activities that can develop a child in physically and the sports activities given to such a child must be in accordance with his characteristics and motor development goals. If the activities provided are not appropriate, then it will inhibit the child's process of growth and development. Hence, for the goals and benefits of sports for children to be achieved, it is important to make use of a practical guide, which a physical education teacher understands and points to the various developmental needs of every child.

The ability to give a child the right sports training is another issue of concern in this subject of discussion. The psychological needs of a child is different from that of another child and this must be understood for them to grow and develop appropriately. If an error occurs in this coaching effort, either from the parents or from the teachers, then it is certain that rather than having desired development, such child will manifest things in the opposite direction. This is simply because they are not the right activities for the child's growth but ones that inhibit and even damage the developmental process of the child.

In the basic term, sports activities for children aged 6-8 years in elementary schools are not intended for great achievements on the part of the student, but rather as a foundation for developing the multilateral abilities of such child. Multilateral development takes care of various skills and motor abilities by using various training methods based on the overall adaptation needs of an individual [6]. This means that every child at a young age needs multilateral skills development as a training foundation as well as his overall motor condition. By developing all these aspects together, such a child will have a balanced functional play of the body parts. And a child with a strong multilateral foundation will be able to achieve better sports performance than a child who does not have this foundation [6]. Also, multilateral coaching is important when a child is faced with various choices of physical activities, both at school and in the sports club. Sometimes, these children fail to determine the most appropriate choice, and they need to make this based on their potentials. Therefore, it is very important for children to be involved in various physical activities, this will help them to better understand their potentials and then deploy them accordingly. According to a research sharing the same opinion as already explained, the multilateral development in the skill development phase is very vital. And the movement variability is shown in the different movement experience with a particular theme [7]. By 
providing a diverse movement experience, children will have a stronger pattern and awareness to be able to perform more efficiently in different situations. And with so many children of this nation who have been built up multilaterally in their early stage, the benefits will certainly be there even when the nursery process is over.

The various explanations given above are to make it known that there series of problems that affect the development of physical education in schools. And this is the concern of the author whose essence to date has been in the activities geared towards improving these situations. Specifically in this work, the author tries to search, study, then constructs a result, in the form of twenty-five models of playing activities through which children can learn physical education in elementary schools and as such, improving their multilateral abilities. And since the results of several playing activity models have been applied in learning physical education in schools, this book is expected to be used as such. It is believed that it will be a material that support effective learning models and ultimately help in the process of child development and the mastery of its multilateral skills in an effort to strengthen the national sports development base and also take it to the next level. It is also hoped that through this book, schools can get a concrete product that can address the problems of physical education coaching in schools.

\section{METHOD}

\section{A. Research Methodology}

This study is a research and development research. And in this case, the development is carried out to get a model of playing activity in learning physical education so as to improve the multilateral abilities of the students. The development procedures followed in this research work is in accordance with those of Borg and Gall. According to Borg and Gall [8], ten steps are to be taken while conducting a development research and then state the possible limitations in the research which will then limit the steps taken. Also, that the application of these development steps could be tailored to the needs of researchers. And considering the limitations of time and funds by the researchers of this work, the study is simplified into 6 steps of development, and these are: (1) analyzing information that has been collected, (2) research-planning, (3) developing initial products, (4) validation by expert and revision, (5) small-scale field trials and product revisions, and (6) large-scale trials and final product revisions.

\section{B. Research Setting}

This research was conducted between April and August, 2018. The research field activities took place at SD $\mathrm{N}$ Pujokusuman Yogyakarta. The training was done 12 times, which was three meetings per week. The duration was 120 minutes for each meeting which is from $7 \mathrm{pm}$ to $9 \mathrm{pm}$.

\section{Population and Sample}

Samples for this study were taken from the elementary schools of the Yogyakarta region's Southern Region coordinator of the Yogyakarta City Education Office. The sampling technique used was purposive sampling, and according to a study, purposive sampling is a sampling technique using certain criteria [9]. And the consideration here is the elementary school children aged 6-10 years.

\section{Data Gathering Technique and Instrument}

The instruments used in this study are observation guidelines, guidelines for value scale questionnaires, field notes and student assessment rubrics.

\section{E. Data Analysis Technique}

The techniques used in this research vary according to the types of data. The technique of analyzing quantitative descriptive data was carried out on: (1) the results of the validation assessment with the material value scale of the experts on the draft game model before the trial; (2) observed data on the game model; (3) observed data on the effectiveness of the playing activity model in the learning process, and (4) the results of the measurement of students' multilateral tests. The range of scores in the questionnaire validation, model observation, and model effectiveness observation are five, namely (1) score 1 for assessment that is very inappropriate, (2) score 2 for assessment that is not appropriate, (3) score 3 for assessment that is quite appropriate, (4) score 4 for assessment that is accordingly, and (5) score 5 for assessment that is very appropriate.Then, quantitative analysis (statistics) uses different statistical tests like the T-test and Paired Sample T-test. In processing the data from expert questionnaires and teachers, the percentage formula [9] used is as follows:

$$
F={ }_{N}^{f} \times 100 \%
$$

$$
\begin{array}{ll}
\text { Notes } & \\
\mathrm{F} & \text { : relative frequency / percentage number } \\
f & \text { : the frequency of the percentage } \\
\mathrm{N} & \text { : total data } \\
100 \% & \text { : constant }
\end{array}
$$

TABLE I. PERCENTAge ClasificAtion

\begin{tabular}{|c|c|c|}
\hline Percentage & Clarification & Mean \\
\hline $0-20 \%$ & Not good & Eliminate \\
\hline $20,1-40 \%$ & Less good & Fix \\
\hline $40,1-70 \%$ & Average & Use (condition) \\
\hline $70,1-90 \%$ & Good & Use \\
\hline $90,1-100 \%$ & Exelent & Use \\
\hline
\end{tabular}

Source: Sugiyono, 2016

\section{RESULT}

\section{A. Product Development Result}

In this section before coming up with the draft product, the researcher tries to describe the data that have been obtained from the results of data collection through preliminary studies during interviews, direct observation and review of the results of existing documents. And based on these, the researcher gave the following descriptions: 
1. In the field, a child is found who is under age and is forced with an excessive training program.

2. Almost every school in the area of Yogyakarta City has no land left for physical/sports activities for its students.

3. Physical Education as a subject is no longer considered as one that is important.

4. Physical Education teachings are mainly done by those who are above 50 years old, therefore, there is a decline in the quality of teaching when it comes to giving examples of demonstrations, classroom management, provision of teaching materials and explanations.

5. Many Physical Education teachers in the city of Yogyakarta have not efficient in class management and material delivery as well as lack of competent teachers that can develop teaching materials due to the inavailability of guidebooks or reference materials, especially in the 2013 curriculum.

6. There are many Physical Education teachers, as well as parents who do not understand how to properly direct sports training for children.

7. A lot of child sports training is developed but it is oriented towards certain achievements.

These findings were used as a reference in making a model to improve the students' multilateral capabilities. Then the next stage is developing the learning model through: material analysis and focus on basic education lessons in the 2013 curriculum, analysis of characteristics of elementary school students aged 6-10 years, analysis of objectives and character, determination of objectives and forms of implementation, forms of subscription payments, small group trials, the mentor completed his revision, and lastly, the creation of a product that would be developed as a model in handling multilateral education.

The first product draft is the development of a play activity model in learning physical education in elementary schools to improve multilateral abilities. The purpose of developing this play activity model can be used to expand multilateral abilities in these children. And the resulting model is expected to have more value in terms of effectiveness when in the phase of using it. What is meant by the effectiveness values include: 1) accommodating to various forms of activities for children in accordance with their developmental characteristics, 2) having elements of attractiveness and level of security that are easily controlled during learning, 3) effectively overcoming limitations of space that has been a major problem in many schools, 4) easy to use and easy for further development by Physical Education teachers. Some of the elements of multilateral abilities targeted as play activities in this model include:

1. Locomotor basic motion: walk, run, jump, skip, gallop, seat scoot or walk down, slide on the floor, jump kick your legs, leap or step in the air.

2. Non-locomotor basic motion: swing and rotate arms, push, pull, lean, twist, bend, stretch, tiptoe.

3. Manipulative basic motion: throw, catch, accompany, kick, hit, catch.

\section{B. Product Expert Validation}

The initial product developed is subjected to experts validation before its trial in a small group. The experts are those that are in the field and two experts were involved: 1) Dr. Ria Lumintuarso, M.Sc, who is an expert in the field of multilateral guidance from UNY and a postgraduate lecturer, and 2) Prof. Dr. Pamuji Sukoco, M.Pd, who is an expert in the field of motor education from UNY and a postgraduate lecturer.

The validation was done by giving an initial draft of the product to the experts. The product which is the playing activity models for teaching Physical Education in elementary school such that it can improve multilateral skills, was accompanied by a validation sheet when given to the experts. This validation sheet is in the form of a questionnaire containing some aspects that deal with the qualities of the game models, suggestions, and comments from the two experts and the results came in the form of scores from a Likert scale of 1 to 5.

The results of the questionnaires obtained from first expert, in the field of multilateral coaching, gave $85.9 \%$ with good category while that of the second expert, in the field of motor education, was $86.04 \%$ with good category. The conlusion with these is that the model is feasible to be used or the field trials could be carried out with some appropriate suggestions for improvement.

TABLE II. PERCENTAGE ClassificATION OF EXPERT VALIDATION

\begin{tabular}{|c|c|c|c|}
\hline Assessment & $\begin{array}{c}\text { Score } \\
\text { percentage }\end{array}$ & Classification & Description \\
\hline Expert & $85.9 \%$ & Good & Use \\
\hline Practitioner & $86.04 \%$ & Good & Use \\
\hline
\end{tabular}

The results according to the experts as shown in Table 2 indicate that the development of the playing activity model in learning Physical Education in Primary School to improve multilateral abilities, are in the Excellent category.

\section{Product Trial Result}

\section{1) Small group trial data}

Based on data obtained in small-scale tests, students tend to be active and happy in moving following the model for movement. And according to the questionnaires data filled by the two experts and one health teacher, a percentage of the overall answers were matched with $85 \%$ assessed aspects. The criteria that have been determined in the development of the model met the criteria of Good and can therefore be used.

Based on the advice of the expert and that of the physical education teachers on the development model that was piloted into a small-scale trial, the product can be revised immediately. The following are the results of the product model of the developed model for playing activities targeted at improving multilateral abilities. This is the draft after a small-scale trial of the product consisting of 25 forms of playing activities: 
TABLE III. SMALL-Scale Trial OF ThE PRODUCT CONSISTING OF 25 FORMS OF PLAYING ACTIVITIES

\begin{tabular}{|c|c|c|}
\hline No & Games Type & Description \\
\hline 1 & Tangan Seribu & $\begin{array}{l}\text { Ball relay with various variations } \\
\text { without moving places }\end{array}$ \\
\hline 2 & $\begin{array}{l}\text { Jembatan } \\
\text { Keseimbangan }\end{array}$ & Bracelet relay, using one foot in turn \\
\hline 3 & $\begin{array}{l}\text { Taman Lari Bangun } \\
\text { Ruang }\end{array}$ & $\begin{array}{l}\text { Run with various forms of building } \\
\text { space }\end{array}$ \\
\hline 4 & Lari Kijang & $\begin{array}{l}\text { Relay back and forth with a combination } \\
\text { of sprint and goal }\end{array}$ \\
\hline 5 & Lari Berkelok & Run in pairs through the goal \\
\hline 6 & Lari Halang Rintang & $\begin{array}{l}\text { Run around with a combination of } \\
\text { obstacles }\end{array}$ \\
\hline 7 & Lari Pak POS & Relay Arranges and Moves Objects \\
\hline 8 & Lompat Kangguru & Combination jump \\
\hline 9 & Balap Kangguru & Jump step relay \\
\hline 10 & Lompat Katak & Vertical Jump \\
\hline 11 & Balap Kelinci & Horizontal Jump \\
\hline 12 & Bowling & $\begin{array}{l}\text { Throw one hand to reach the target with } \\
\text { a tassel ball }\end{array}$ \\
\hline 13 & Pecah Piring & $\begin{array}{l}\text { Throw one hand to reach the target with } \\
\text { a ball }\end{array}$ \\
\hline 14 & Monster & Throw shifts the target \\
\hline 15 & Roket Terbang & $\begin{array}{l}\text { Throw one hand to reach distance with } \\
\text { the child's javelin }\end{array}$ \\
\hline 16 & Dwi Lomba & Combine sprint and throw \\
\hline 17 & Formula One & $\begin{array}{l}\text { Relay with a combination of sprint, } \\
\text { goalkeeper, and slalom }\end{array}$ \\
\hline 18 & Ular Naga & $\begin{array}{l}\text { The game runs, dribbles, and passes the } \\
\text { ball }\end{array}$ \\
\hline 19 & Bola Tembak & Herding and shotting (shooting) targets \\
\hline 20 & Kasti Tendang & Modification of ball games \\
\hline 21 & $\begin{array}{l}\text { Terowongan } \\
\text { Panjang }\end{array}$ & $\begin{array}{l}\text { Combination of Roll Movement, } \\
\text { Crawling and Running }\end{array}$ \\
\hline 22 & Lempar Tonis & Pair Catch Throw \\
\hline 23 & $\begin{array}{l}\text { Lempar } \\
\text { Bersambung }\end{array}$ & Catch the Relay Relay \\
\hline 24 & Lempar Merah Putih & Capture and Sprint \\
\hline 25 & Tali Ajaib & Modification of Games Using Rope \\
\hline
\end{tabular}

\section{2) Large group trial data}

Based on the trial with the large group, the results from 2 experts and 2 training teachers gave $98.8 \%$, meaning that the model can be used, and the criteria are very good as well. Based on the criteria that have been determined during the development of the models, it can be used to support effective learning and can also help children's growth and development of multilateral skills.

TABLE IV. Results Percentage of Results of LARGE GROUP TRIALS

\begin{tabular}{|c|c|c|c|}
\hline Asessment Aspect & $\begin{array}{c}\text { Score } \\
\text { percentage }\end{array}$ & $\begin{array}{c}\text { Mean } \\
\text { scores }\end{array}$ & Description \\
\hline Material & $100 \%$ & 5,0 & Use \\
\hline Implementation & $98.43 \%$ & 4,9 & Use \\
\hline
\end{tabular}

Considering Table 3, which is the result of trial on large group, we have the following conclusions:

a. The aspects of material content that includes basic multilateral movement elements, conformity with physical education curriculum in elementary schools, and conformity with the characteristics and developing competence in elementary school students, gave $100 \%$. Based on predetermined criteria, the content aspect of the product models met good criteria, so it can be used.

b. The implementation aspects which include ease, security, effectiveness, tools, goals, student interests and the usefulness of the developed model gave 98.43\%. Also, based on the criteria that have been established, the content aspect of the models met the criteria very well, so that it can be used

\section{1) Efectivity Test and T-Test}

Results of the Normality Test for large groups of Kolmogorov-Smirnov Test data.

TABLE V. Results of Data Normality Test (N=60)

\begin{tabular}{|l|l|c|c|}
\hline No & \multicolumn{1}{|c|}{ Variable } & Asymp. Sig & Description \\
\hline 1 & 3 Hop (Pre Test) & 0.552 & Normal \\
\hline 2 & 3 Hop (Post Test) & 0.402 & Normal \\
\hline 3 & 10 Meter Speed Hop (Pre Test) & 0.972 & Normal \\
\hline 4 & 10 Meter Speed Hop (Post Test) & 0.998 & Normal \\
\hline 5 & Lempar Atas (Pre Test) & 0.269 & Normal \\
\hline 6 & Lempar Atas (Post Test) & 0.470 & Normal \\
\hline 7 & Lempar Samping (Pre Test) & 0.789 & Normal \\
\hline 8 & Lempar Samping (Post Test) & 0.272 & Normal \\
\hline
\end{tabular}

The results above show that each group, with a total sample of 60 children, has Asyimp. Sig> 0.05, meaning that they are normally distributed. Then next is the table showing the T-test:

TABLE VI. RESUlt OF T-TEST ANALYSIS

\begin{tabular}{|c|l|c|c|}
\hline No & \multicolumn{1}{|c|}{ Variable } & Df & Sig (2-tailed) \\
\hline 1 & 3 Hop (Pre Test - Post Test) & 59 & 0.045 \\
\hline 2 & $\begin{array}{l}\text { 10 Meter Speed Hop (Pre Test - Post } \\
\text { Test) }\end{array}$ & 59 & 0.000 \\
\hline 3 & Lempar Atas (Pre Test - Post Test) & 59 & 0.000 \\
\hline 4 & Lempar Samping (Pre Test - Post Test) & 59 & 0.007 \\
\hline
\end{tabular}

The table above shows that there are significant differences between the results of the pre-test scores, feet (3 hops, 10 meters speed hop), arms (top throw, throw down) and post-test. This means that there is an effect of $12 \mathrm{x}$ treatment meeting on the results of multilateral measurements of foot and hand movements since the value of Sig (2-tailed) 3 Hop 0,045 < 0,05, Sig score (2-tailed) 10 Meters Speed hop 0,000 < 0,05, Sig score (2-tailed) Lempar Atas $0,000<0,05$ and Sig score (2-tailed) Lempar Samping $0,007<0,05$.

\section{DISCUSSION}

\section{A. Multiletral Development}

Multilateral, also called multiskill, or "vieleseitige" in German, is the development of various motor skills and abilities with the adaptation of various training needs in order to develop overall adaptation. And every child, at a young age, needs the training foundation for developing his multilateral skills as well as his overall motor condition. [6]. 
And when all these different aspects are integrally developed, a harmonious body will be achieved. This is in accordance with the work of Krasilshchikov, that stated that, "The objective is to increase endurance and strength, develop speed, improve flexibility, and refine coordination, thus achieving a harmoniously developed body. In addition, such athletes were supposed to have a superior body form, increased self-esteem and strong personality" [11]. Considering the opinions of Krasilshchikov, we can say that the aim of multilateral development is to increase endurance and strength, develop speed, increase flexibility, and improve coordination, so that a harmoniously developed body system coordination can be achieved [11]. Apart from this, children will have a superior body shape, increased selfesteem, and a strong personality. For this reason, children who have a strong foundation in multilateral development will perform better in sports compared to children who do not have this foundation [12]. Also, multilateral coaching is important in situations where a child faces different physical activities, either at school or in a sports club. Most times, children are faced with the challenges of making the right choices in terms of picking the most appropriate physical activities or sports for their potential. Therefore, it is very important for children to participate in various physical activities, this will help them to identify and better understand their abilities in various physical activities.

Considering age, multilateral development can begin from age 6 to 13 years, which is the initiation stage. This will help the child to have a solid foundation before entering specialization stage [7]. At the initiation stage, multilateral development is done by doing physical movements and training programs with low intensity, The emphasis here is making the child happy doing what he is doing. After this stage comes the Athletic Formation stage. This is a sports foundational stage with an increased intensity of physical activities, which aims at preparing the child for specialized activities. In Figure 1 below, we can see the ratio between multilateral activities and specialized activities based on the child's age.
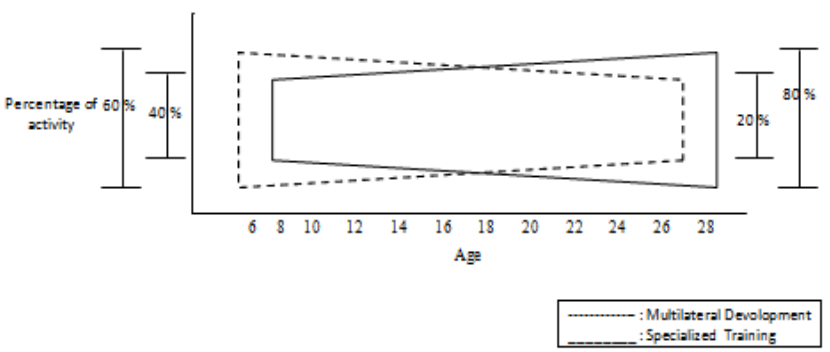

Fig. 1. the ratio between multilateral activities and specialized activities based on the child's age.

(Source: Tudor O. Bompa, 2000)

The Figure 1 above shows that the ratio of multilateral coaching is greater than that of specialization training at the age of 6 to 12 years. Then from age 14 years and above, specialization exercises grow larger while multilateral training decreases. From the description above, it can be seen that children at the primary school level are at the age of multilateral coaching.

\section{B. Multilateral in the develoment and growth of children}

It is a fact that professionalism has been introduced into child sports. This is not helping those children as it is counter-productive to their development and in most times, these children fail to become athletes in the future [13]. Based on this fact, , exercise does not inhibit or damage the process of child's development. Also, a child is at a vulnerable position when in the level of growth and development since he experiences a rapid growth here. And judging from the physical growth curve shown in Figure 2, it is clear that children experience rapid growth (growth spurts) between the ages of 10 and 13 years for girls and 12 to 15 years for boys.

In this rapid growth phase, a child does not have the power tocontrol his own body, so that his movement and coordination are disrupted. Children experience clumsiness and disharmony in coordinatinating their movements because of the rapid physical growth. In that phase, a child cannot find the appropriate movement for himself. Therefore, various coordinate movements and bio-motor abilities need to be done, so that children can always follow the most suitable path of physical growth.

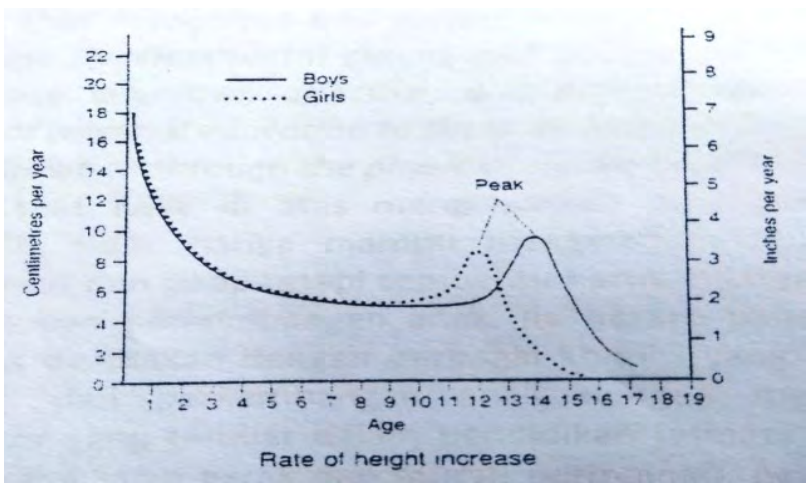

Fig. 2. Physical growth curve based on age. (Source: Thompson, 1991)

Children can experience difficulty in making some patterns of motion, but do other movememts with ease. This makes them like a particular movement and at the same time hates the other one. Even though in this phase the child is still experiencing rapid growth so he does not know the potential of the real motion which is the potential of his talent. And multilateral coaching provides children with this greatest opportunities of discovering their true potential with regards to motion [11]. Limiting the number of activities a child is exposed to can affect the child in the sense that he might not have the potential for the only activity or the few ones he is exposed to.

Another advantage of multilateral coaching in the rapid growth phase of a child is the existence of a wide range of motion experiences. This is vital because it helps the child to make adjustments between growth and adaptation of movement. As a result of this, the child grows quickly while still maintaining his coordination ability.. More so, it allows the child to be able to improve his physical abilities and skills towards the next phase of his growth. This is more important in girls as girls from 14 years and above experience a 
decrease in skills and physical abilities due to the fact that they experience uncontrolled growth evidence in the enlargement of their hips and chests. These make them to be slow during movements. And without routine and sustainable bio-motor activities, they will stop any form of exercise because of these conditions thereby decreasing their physical abilities and skills than it was initially. This is true according to a study which has it that a strong foundation in multilateral activities has a positive influence on a child as it can produce: improvemts in slow or sluggish performance, a very good appearance at the age of 18 or more, physiological and psychological maturity in the child, consistency in the child's performance in sports activities, longer peak performance in the child with less injury [11]. But in the other way, early specialization will have a negative effect on the child's performance as he will experience a rapid one and then start declining. His best performance is achieved at 15-16 years of age due to rapid adaptation, inconsistently appearing in competitions, shorter peak periods and having more injuries due to forced adaptations For these reasons, multilateral coaching is very important for children at the stage of rapid growth so that they can follow their physical growth by harmonizing various motion skills and good biomotor abilities.

\section{Multilateral in learning Physical Education}

In Indonesia, Physical Education is an integral part of the education system with the following aims: to develop various aspects of health, physical fitness, movement skills, critical thinking skills, emotional stability, social skills, reasoning, moral actions through physical activities planned systematically within the framework of the national education system. And the function of Physical Education, as a subject, is to develop the: organic aspects relating to the body organs, neuromuscular aspects relating to the harmonization of the body nerves and muscles, perceptual aspects relating to the problems in responding to external cues or push, cognitive aspects relating to the knowledge and understanding of the subject and then the social and emotional aspects. And this tells us that Physical Education does not just mean physical movement but contain other important aspects and so requires that the teacher is competent enough to perform his basic duties in accordance with what is mandated in the teaching scheme. According to Kelly, "Educator has an obligation to create a learning environment that recognizes and fosters individual potential. And because students follow developmental stages and growth patterns, education should enhance cognitive, affective, and psychomotor learning. The contribution of physical education to these developmental patterns is the essence of education through the physical". [15]

With this, it is evident that Physical Education teachers are not only to develop motor skills, cognitive skills and attitudes, but must base all these on the pattern of child growth and development. This means that physical education must be created with various conditions that are appropriate to the growth and development of the child.Aside this, the teacher needs to ensure that the learning process can run well in various situations and transfer the substance of education not only to be able to do, but how physical education is a vehicle for; "learning to do, learning to know, learning to be and learning to live together"

More so, judging form the growth and development of a child, especially those relating to motor, the basic motion is divided into two, namely: fine motor and gross motor. And the basic motion skills consist of locomotor, non-locomotor, and manipulative skills [16]. And it is important that the foundation of all these basic movements mentioned above need to be laid in the formation stage towards having quality physical skills at the next level. To this end, there is a need for making curriculum and syllabus for Physical Education while also mandating the teachers to implement them while teaching the subject. The study of this curriculum in Indonesia is contained in the 2013 Curriculum. And the basic concept that needs to be considered in this case is how the teachers understand the pattern of development with regards to children's motor movements and how the systematic learning is being done. All these need to be understood and implemented. Figure 3 presents basic movements as a foundation for the next stage, and then the specialization that needs to be given while teaching Physical Education in schools.

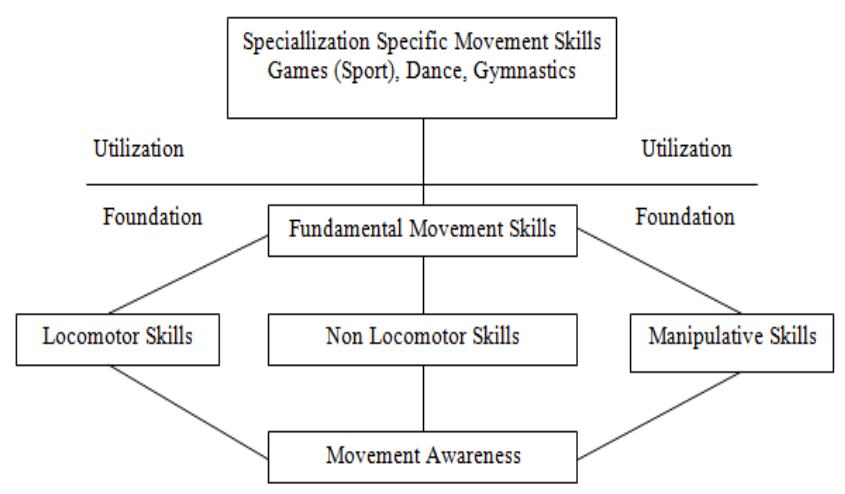

Fig. 3. Basic movements

Looking at Figure 3 above, it can be concluded that learning basic skills has some characteristics which include:

1. Learning skills is a long-term process in which a variety of basic rules are needed, such as those from the known to the unknown, from the simple to the complex, from the general to the special, and from the easy to difficult.

2. Learning skills need to be properly designed in accordance with the stages of child motor development.

3. General and basic skills need to be provided in various forms, before learning the special ones which are known as specialties in sports.

4. Because learning skills is a long-term process, it is necessary to have fun and entertaining in the learning process.

\section{ACKNOWLEDGMENTS}

The authors wish to specially thank Yogyakarta State University, for accommodating us to the completion of this research. And to all the lecturers that guided us, particularly our supervisor, Dr. Sri Winarni, M.Pd, we say thank you. 
And finally want to appreciate all our friends in the faculty of Sport Science 2016.

\section{REFERENCES}

[1] C. Himberg, G. E. Hutchinson, and J. M. Roussell, Teaching secondary physical education: Preparing adolescents to be active for life, Canada: Human kinetics, 2003.

[2] Liukonen, J., Psykology for physical educator: Studen in focus, Canada: Human kinetics, 2007.

[3] J. R. Marow, A. W. Jackson, Measurement and evaluation in human performance, Canada: Human Kinetics, 2005.

[4] Suherman, A., Orientasi Nilai Kurikulum Guru dan implikasinya pada pengembangan kurikulum dan pembelajaran pendidikan jasmani," Disertasi, Bandung: Universitas Pendidikan Indonesia, 2007.

[5] Rink, J. E., Teaching Physical Education for Learning. Fourth Edition, New York: McGraw Hill, 2002.

[5] Siedentop, D., Developing Teaching Skills in Physical Education, California: Mayfield Publishing Company, 1991.

[6] Bompa, Tudor O., Periodization Theory and Methodology of Training, USA: Human Kinetics, 1999.

[7] Carl Gabbard, Elizabeth LeBlanc, dan Susan Lowy, Physical Education for Children, Building the Foundation, USA: Prentice Hall New Jersey, 1987.

[8] Borg, W.R. \& Gall, M.D., Educational research (an introduciton). 7th Edition, New York: Longman, 2003.

[9] Sugiyono, Metode penelitian dan pengembangan, research and development. Bandung: CV Alfabeta. 2016.

[10] Ambo Upe \& Damsid, Asas-asas multiple research. Yogyakarta: Tiara Wacana, 2010.

[11] Krasilshcikov, O., "Multilateral Training: Re-examining the Concept's Practicality," MR International Journal Of Applied Health Sciences, 10(1), 2-10. $\quad$ (2014) $\quad$ Retrieved https://www.researchgate.net/publication/283571023

[12] Bompa, Tudor O., Total Training For Young Champions, USA: Human Kinetics, 2000.

[13] Jacqueline D. Goodway and Leah E. Robinson, "Developmental Trajectories in Early Sport Specialization: A Case for Early Sampling from a Physical Growth and Motor Development Perpective," Journal of Kinesiology Review Human Kinetics Inc, 2015,4,267-278, 2015. Retrieved from https://dx.doi.org/10.1123/kr.2015-0028

[14] Thompson, Peter Jl., Instroduction to Coaching Theory, London: IAAF, 1991.

[15] Luke Kelly E., Developing the Physical Education Curriculum, An Achivement-Base Approach, USA: Human Kinetics, 2004.

[16] Malina, Robert M, Bouchard, and Oded, Growth, Maturation, and Physical Activity, USA: Human Kinetic, 2004. 